\title{
Mengkaji Konsep Kalender Islam Internasional Gagasan Mohammad Ilyas
}

\author{
Siti Tatmainul Qulub \\ UIN Sunan Ampel Surabaya | nungky_diamond@yahoo.com
}

\begin{abstract}
Abstrak
Bagi umat Islam, kebutuhan akan sebuah kalender yang universal merupakan hal yang mendesak karena banyak kegiatan ibadah umat Islam terkait dengan waktu. Namun hingga saat ini Kalender Islam yang satu dan berlaku universal belum terwujud. Saat ini umat Islam di dunia masih menggunakan kalender lokal atau regional yang berlaku di wilayah atau negara masing-masing.Salah seorang peneliti yang konsen terhadap masalah Kalender Islam adalah Mohammad Ilyas. Ia adalah seorang astronom Muslim dari Malaysia yang memperkenalkan konsep Garis Tanggal Qamariyah Internasional (International Lunar Date Line). Di samping konsep yang digagas oleh Moh. Ilyas, sebenarnya masih ada beberapa konsep Kalender Islam Internasional yang telah digagas oleh ilmuwan lain. Namun hingga saat ini Kalender Islam yang berlaku Universal masih belum terwujud. Tulisan ini mengkaji tentang konsep Kalender Islam Internasional yang digagas Moh. Ilyas dan pengaruhnya terhadap penyelesaian perbedaan kalender Islam. Dari hasil kajian, ditemukan bahwa konsep Garis Tanggal Qamariyah Internasional yang ditawarkan Moh. Ilyas menyisakan masalah tentang mathla' (karena garis tanggal selalu berubah-ubah tergantung konfigurasi Bulan dan Matahari), dan agak sulit diterapkan karena umat Islam menggunakan double standart yakni Kalender Masehi dan Hijriyah. Konsep kalender Moh. Ilyas memang belum bisa menyelesaikan masalah perbedaan Kalender Hijriyah, namun ia memberikan pengaruh terhadap terbentuknya kriteria visibilitas hilal dan model kalender Islam, yaitu kalender zonal dan kalender universal sebagai upaya penyatuan kalender Islam.
\end{abstract}

\section{Kata kunci: Moh. Ilyas, Kalender Islam Internasional, Perbedaan}

\section{Pendahuluan}

Dalam kehidupan, umat manusia membutuhkan kalender sebagai sistem penjejak, pengatur dan pembagi waktu. Terutama bagi umat Islam, kebutuhan akan sebuah kalender yang universal merupakan hal yang mendesak karena banyak kegiatan ibadah umat Islam terkait dengan waktu, seperti puasa Ramadhan, Idul Fitri, Idul Adha, dan sebagainya. Umat Islam di seluruh dunia pada bulan-bulan tersebut mengalami ketidakpastian tentang kapan mereka harus memulai puasa dan hari raya.Ketika usia peradaban Islam hampir menyentuh angka 1,5 milenium, peradaban ini masih belum memiliki kalender Islam pemersatu. Padahal setiap peradaban besar yang lahir ke dalam panggung sejarah pasti memiliki suatu sistem penanggalan sesuai dengan 
pandangan hidup dan nilai yang dikembangkan oleh peradaban itu. ${ }^{1}$

Saat ini dikenal tiga sistem kalender atau penanggalan yang didasarkan pada waktu edar bendabenda langit. Pertama,Kalender Masehi yaitu penanggalan yang didasarkan pada peredaran bumi mengelilingi matahari atau dikenal dengan sistem Syamsiyah (Solar System).Kedua, Kalender Hijriyah yaitu penanggalan yang didasarkan pada peredaran bulan menglilingi bumi yang disebut juga dengan sistem Qamariyah (Lunar System). Dan ketiga, lunisolar calendar yang merupakan gabungan ataskeduasistem di atas.

Dalam agama Islam digunakan dua sistem kalender untuk kepentingan pelaksanaan ibadah yaitu Kalender Masehi dan Hijriyah. Beberapa aspek rukun Islam terkait erat dengan kedua sistem tersebut. Misalnya ibadah shalat yang menggunakan sistem peredaran Matahari, dan ibadah puasa serta haji yang menggunakan sistem peredaran bulan.

Kalender Masehi atau Syamsiyah telah menjadi satu kalender tetap yang berlaku Internasional. Namun untuk Kalender Hijriyah (Qamariyah atau Islam) sampai saat ini belum menjadi satu kalender yang tetap dan berlaku universal. Umat Islam di dunia saat ini masih menggunakan kalender lokal atau regional yang berlaku di wilayah atau negara masing-masing, seperti Kalender Islam Saudi Arabia, India, Inggris, Amerika, Libya, Indonesia, Iran, dan sebagainya.

\footnotetext{
1 Syamsul Anwar, Makalah "Kalender Hijriah Global, Penyatuan Jatuhnya Hari Arafah”, 1.
}

Oleh karena itu, sebuah Kalender Hijriyah yang berlaku universal sangat diperlukan. Dengan adanya sebuah Kalender Islam yang seragam dan berlaku universal dapat menjadi lambang persatuan umat Islam karena ada kesatuan waktu dalam melaksanakan ibadah. Di samping itu,

Dalam membentuk sebuah Kalender Islam yang Universal, diperlukan sebuah penetapan awal bulan Hijriyah yang seragam pula karena pembuatan sebuah kalender sangat terkait dengan penetapan tanggal satu setiap bulannya. Bila tanggal satu setiap bulan sudah dapat ditetapkan dengan serempak, akan sangat mudah membuat sebuah Kalender. Berbagai usaha telah dilakukan baik melalui penelitian maupun pertemuan untuk membentuk sebuah Kalender Islam Internasional. Namun sampai saat ini belum ada satu titik temu karena banyak metode dan kriteria yang digunakan untuk menetapkan tanggal satu dalam bulan Qamariyah. Dengan demikian, perlu kesepakatan metode dan kriteria yang akan dijadikan sebagai acuan bersama umat Islam seluruh dunia. Bila perbedaan ini terus dibiarkan, maka akan menjadi masalah akut yang memecah persatuan umat Islam, bahkan dapat berimbas pula ke aspek politis, ekonomis dan sosiologis.

Dalam konsep Kalender Islam Internasional, Mohammad Ilyas, seorang astronom Muslim dari Malaysia dikenal sebagai seorang peneliti yang konsen terhadap masalah ini dan pertama kali menggagas penyatuan kalender Islam. Melalui penelitiannya selama bertahun-tahun, Ilyas 
memperkenalkan konsep Garis Tanggal Kamariah Antar Bangsa (International Lunar Date Line). Garis tersebut dihubungkan antar wilayah guna mendapatkan keseragaman hilal. Mohammad Ilyas membagi bumi menjadi tiga zona kalender, yaitu zona barat, tengah dan timur. Dengan pembagian bumi menjadi 3 zona tersebut, kemudian muncul istilah kalender zonal dan kalender universal.

Kalender zonal merupakan kalender yang membagi-bagi bumi menjadi zona-zona kalender, ada dua, tiga dan empat zona kalender di mana pada masing-masing zona berlaku tanggal sendiri yang mungkin sesuai atau tidak sesuai dengan tanggal pada zona lain. Sedangkan kalender universal (unifikasi) menghendaki prinsip satu hari satu tanggal dan satu tanggal satu hari di seluruh dunia.

Beberapa kalender yang merupakan kalender zonal adalah kalender Ilyas, kalender usulan Qasum, kalender Hijriyah Universal yang dibuat oleh Muhammad Syaukat 'Audah. Sedangkan kalender Jamaluddin Abdur Raziq yang disebut dengan kalender unifikasi termasuk kalender universal. Kalender-kalender tersebut muncul setelah usulan penyatuan kalender Islam oleh Mohammad Ilyas. Namun, tidak semua setuju dan menerima konsep yang ditawarkan Ilyas. Ketidaksetujuan itu diwujudkan dengan membentuk konsep kalender sendiri dengan menambah dan mengurangi dari konsep Moh. Ilyas. Akhirnya muncul banyak konsep Kalender Islam Universal.
Walaupun banyak konsep kalender Islam Universal yang ada, salah satunya konsep kalender Islam Universal Moh. Ilyas, namun sampai saat ini Kalender Islam Universal yang dijadikan pedoman untuk seluruh umat Islam di dunia belum juga terwujud. Perbedaan Kalender Hijriyah juga terus berlanjut. Berangkat dari hal ini, penulis tertarik untuk mengkaji tentang konsep Kalender Islam Internasional yang digagas Mohammad Ilyas yang merupakan pelopor dalam perumusan Kalender Islam Internasional, dan sejauh mana konsep Kalender Mohammad Ilyas tersebut mempengaruhi penyelesaian perbedaan Kalender Hijriyah.

\section{Kalender Islam}

Kalender adalah sebuah sistem pengorganisasian waktu untuk penghitungan waktu selama periodetertentu.Secara konvensi, hari adalah unit kalenderterkecil,sementara untuk pengukuran bagian darisebuah hari digunakan sistem penghitungan waktu(jam, menit, dan detik). Beberapa sistem kalendermengacupada suatu siklus astronomi yang mengikutiaturan yang tetap, tetapi beberapa sistem kalender adayang mengacu pada sebuah aturan yang abstrak danhanya mengikuti sebuah siklus yang berulang tanpamemilikiarti secara astronomis. Ada kalender yangdikodeberdasarkan hukum tertulis, tapi ada juga yangdisampaikanmelalui pesanpesan moral.

Agama Islam mengatur dengan jelas tentang perhitungan dan pengorganisasian waktu umat 
manusia. Sebagaimana yang dijelaskan dalam kitab suci al-Qur' an surat al-Taubah ayat 36-37 tentang perhitungan kalender Islam yang artinya: "Sesungguhnya bilangan bulan pada sisi Allah adalah dua belas bulan, dalam ketetepan Allah di waktu Dia menciptakan langit dan bumi, di antaranya empat bulan haram. Itulah (ketetapan) agama yang lurus."

Secara umum terdapat tiga sistem kalender dilihat dari acuannya pada siklus benda langit. Pertama, adalah sistem kalender Masehi (Syamsiyyah) atau solar calendar, yaitu sistemkalender yang penghitungannya berdasarkan padaperjalananbumi saat melakukan revolusi mengorbitpada matahari. Kedua,kalender Hijriyah (Qamariyah) atau lunar calendar yang berdasarkan pada perjalanan bulan selamamengorbit (ber-revolusi terhadap) bumi.Ketiga, lunisolar calendar yang merupakan gabungan ataskeduasistem di atas. Kalender lunisolar memilikiurutan bulan yang mengacu pada siklus fase bulan, namun pada setiap berbagai tahun tertentu ada sebuahsisipan (intercalacy month) diberikan agar kalenderini tetap sinkron dengan kalender musim (solar calendar), seperti Kalender Yahudi, China, dan Kalender Arab pra-Islam. ${ }^{1}$

Istilah kalender bisa disebut juga dengan târîkh, taqwîm,almanak, dan penanggalan. Istilah-istilah tersebutpada prinsipnya memiliki makna yang sama. ${ }^{2}$ Adapun

\footnotetext{
${ }^{1}$ Tono Saksono, Mengkompromikan Rukyat \& Hisab(Jakarta: P.T. Amythas Publicita, 2007), 47.

Departemen Pendidikan dan
Kebudayaan, Kamus Besar Bahasa
}

Kalender Islam adalah murni lunar kalenderyang mengikuti siklus fase bulan tanpa ada keterkaitandengan tahun tropis. Kalender ini terdiridari dua belas bulan Qamariyah, awal bulannya ditandai dengan penampakan hilal (visibilitas hilal) setelah matahariterbenam(Maghrib). Kalender ini mulai digunakanpada masa Khalifah 'Umar bin Khattab dengan mendasarkan pada hijrah Nabi SAW dari Mekah keMadinah.

Kalender Hijriyah mengikuti pergerakan bulan sinodik(synodic month) yang memiliki 12 x 29,53 hari, sehingga satu tahun kalender Hijriyah hanya memiliki354,36707 hari. Dengan demikian, kalender Islamsecarakonsisten lebih pendek sekitar $\quad 11,256 \quad$ hari darikalenderSyamsiyah yang memiliki hari 365,25 hari dalam satu tahun.

Dalam mendefinisikan satu hari, semua sistem kalendersepakat bahwa satu hari adalah perjalananbumi berotasi pada sumbunya satu kali putaran, yang mengakibatkan efek gerak semu mataharimengelilingi bumi yaitu selama 24 jam. Yang membedakandi antara kalender-kalender tersebut yaitupendefinisiandimulainya sebuah hari. Dalam Kalender Masehi,awal hari didefinisikan pada tengah malam(pukul 24:00 atau 00:00), sedangkan dalam Kalender Islam, awalhari dimulai pada saat matahari terbenam di ufukbarat.

Sebab Perbedaan Kalender Islam Perbedaan Kalender Hijriyah hampir menjadi tradisi karena

Indonesia (Jakarta: Balai Pustaka, 2008), 380 dan 904. 
hampir setiap tahun terjadi terutama di Indonesia. Penyelesaian dalam penentuan Kalender Hijriyah ini semakin pelik. Hal ini sebenarnya telah disadari oleh banyak ahli hisab dan ru'yat di Indonesia. Dari berbagai penelitian disebutkan bahwa masalah yang menyebabkan Kalender Hijriyah belum bisa bersatu adalah belum seragamnya acuan yang dipakai dan belum adanya kriteria baku bagi visibilitas hilal yang dapat diikuti semua ahli hisab. Dalam masalah tersebut, dua hal kunci yakni visibilitas hilal dan garis tanggal Qamariyah akan dipaparkan sebagai berikut:

\section{a. Visibilitas Hilal}

Awal bulan dalam kalender Hijriyah ditandai berdasarkan penampakan hilal (bulan sabit pertama setelah konjungsi yang dapat dilihat dengan mata telanjang) sesaat sesudah matahari terbenam. Alasan utama digunakannya penampakan hilal karena kemudahan dalam menentukan awal bulan dan dalam mengenali tanggal dari perubahan bentuk (fase) bulan. Ini berbeda dari kalender syamsiah (kalender matahari) yang menekankan pada keajegan (konsistensi) terhadap perubahan musim, tanpa memperhatikan tanda perubahan hariannya.Dengan demikian, satu bulan dalam penanggalan Hijriyah dimulai dari penampakan hilal sampai penampakan hilal berikutnya.

Bisa tidaknya hilal teramati bergantung pada waktu dan tempat. Kebergantungan terhadap waktu terkait dengan waktu terbenamnya matahari dan hilal serta usia hilal sendiri, yakni selang waktu penampakan hilal dari saat konjungsi; sedangkan kebergantungan terhadap tempat erat kaitannya dengan posisi geografis pengamat di muka bumi. Sebenarnya masih ada faktor lain yang turut mempengaruhi penampakan hilal, yaitu kecerlangan langit senja dan refraksi angkasa.

Cahaya hilal sangat lemah bila dibandingkan dengan cahaya matahari maupun cahaya senja, sehingga sangat sulit untuk bisa mengamati hilal yang masih berusia sangat muda. Semakin muda usia bulan semakin dekat ia dengan matahari, sebaliknya makin tua usia bulan, ia makin menjauhi matahari. Pada saat konjungsi, bulan dan matahari berada di bujur ekliptika yang sama. Setelah lewat konjungsi, keduanya pun berangsur-angsur menjauh.

Pada hilal yang sangat muda, beda azimut antara bulan dan matahari amat kecil (akibatnya jarak sudut antara keduanya pun kecil) demikian pula dengan luas hilal yang memantulkan sinar matahari. Karena dekatnya jarak-sudut bulan-matahari ini, hilal akan terbenam beberapa saat setelah matahari terbenam dan dengan tipisnya sabit hilal yang memantulkan sinar matahari berarti diperlukan latar yang gelap untuk bisa mengamati penampakan hilal.

Dengan demikian, pengamatan hilal (rukyatul hilal) merupakan hal yang sangat sulit, sebab meskipun hilal berada di atas ufuk saat matahari terbenam ia belum tentu bisa diamati. Hal ini karena cahaya hilal yang amat lemah itu kalah dengan cahaya senja. Agar mata manusia dapat mengamati hilal dengan baik diperlukan kondisi 
langit yang gelap. Namun,semakin muda usia hilal semakin dekat kedudukannya dengan matahari, sehingga tidak ada cukup waktu untuk menunggu senja meredup agar hilal bisa teramati. Dengan kata lain, hilal sudah terbenam saat langit masih cukup terang. Sebenarnya dengan makin meningkatnya usia hilal, kesulitan tersebut dengan sendirinya akan teratasi karena pada saat itu beda azimut bulan-matahari sudah membesar sehingga pengamat punya cukup waktu untuk menyaksikan hilal di atas ufuk setelah matahari terbenam maupun menunggu redupnya senja.

Di samping itu, angkasa bumi penuh dengan partikular-partikular berbagai ukuran. Debu-debu dan molekul uap air yang ada di angkasa dapat juga mempengaruhi penampakan hilal. Debu-debu dan molekul uap air di dekat horison dapat membiaskan cahaya hilal, mengurangi cahaya sampai dengan $40 \%$ dari yang seharusnya sampai ke mata pengamat. Ketika hilal berusia sangat muda, keadaan ini lebih parah karena cahaya hilal bisa "habis" di jalan sebelum sampai ke mata kita. Karena itulah, tempat yang lebih tinggi meskipun mempunyai medan pandang yang lebih luas dan dalam ke horison kurang menguntungkan, sebab makin besar serapan cahaya hilalnya di horison bila dibandingkan dengan tempat yang lebih rendah.

\section{Dari kesulitan-kesulitan}

tersebut, kemudian dibuat kriteria kenampakan (visibilitas) hilal untuk dapat menentukan permulaan bulan dalam kalender Hijriyah.Faktor yang dominan dalam penampakan hilal adalah jarak sudut bulan-matahari dan tinggi hilal saat matahari terbenam. Orang-orang Babilonia kuno sudah memiliki kriteria sendiri untuk hal ini, bahwa hilal dapat dilihat saat hilal mencapai usia lebih dari 24 jam setelah konjungsi. Fotheringham, dengan menggunakan hasil pengamatan orang-orang Yunani, menurunkan kriteria visibilitas hilal berdasarkan beda azimut bulan-matahari dan tinggi hilal dari ufuk. Telaah Fotheringham ini kemudian dikembangkan oleh Maunder yang selanjutnya disempurnakan lagi dalam Indian Astronomical Ephemeris. Dari ketiga kriteria ini, untuk beda azimut yang membesar, tinggi hilal dari ufuk yang diperlukan agar hilal dapat teramati makin berkurang. Jadi tinggi hilal untuk beda azimut 10 derajat, lebih rendah daripada tinggi hilal bila beda azimutnya 5 derajat.

Seorang berkebangsaan

Prancis, A. Danjon, pada tahun 1932 mengadakan telaah atas pengurangan efek tanduk bulan sabit dan hasil penelitiannya menunjukkan bahwa jarak sudut bulan-matahari sebesar 7 derajat merupakan batas bawah hilal dapat teramati oleh mata telanjang. Selanjutnya, pada tahun 1988 Mohammad Ilyas menyempurnakan kriteria di atas dan menghasilkan angka 10,5 derajat untuk jarak sudut bulan-matahari pada beda azimut 0 derajat agar hilal dapat dilihat. Danjon dan Ilyas mensyaratkan satu hal, yakni hilal harus berada pada suatu ketinggian yang cukup untuk dapat dirukyat oleh semua orang yang secara geografis berada dalam wilayah (regional) yang sama.

Bagi para ahli hisab di Indonesia, ada dua kriteria yang dijadikan acuan untuk penentuan awal bulan. Pertama, kriteria tinggi 
hilal yang memungkinkan hilal dapat dirukyat. Secara umum tinggi hilal adalah 2 derajat di atas ufuk saat matahari terbenam, namun hal ini belum disepakati oleh semua ahli hisab.Kedua, kriteria konjungsi sebelum matahari terbenam, yang merupakan kriteria khusus untuk daerah di sekitar khatulistiwa. Dengan kriteria ini, hanya perlu dibandingkan waktu terjadinya konjungsi dengan waktu terbenamnya matahari. Ketiga, usia bulan tidak kurang dari 8 jam setelah konjungsi agar hilal dapat diamati.

Kriteria visibilitas hilal lainnya adalah yang ditetapkan oleh IICP (International Islamic Calendar Programme). Kriteria tersebut terbagi atas tiga bergantung pada segi yang diperhitungkan, yaitu pertama, kriteria posisi bulan dan matahari; batas-bawah tinggi hilal agar hilal dapat diamati adalah 4 derajat dengan syarat beda azimut bulan-matahari lebih besar dari 45 derajat, sedangkan bila beda azimutnya 0 derajat diperlukan ketinggian minimal 10,5 derajat. Kedua, kriteria beda waktu terbenam; hilal dapat teramati bila waktu terbenamnya minimal lebih lambat 40 menit dari waktu terbenamnya matahari. Untuk daerah di lintang tinggi, terutama di musim dingin, diperlukan beda waktu yang lebih besar. Ketiga, kriteria umur bulan dihitung sejak konjungsi; hilal dapat diamati bila berumur lebih dari 16 jam untuk pengamat di daerah tropis dan berumur lebih dari 20 jam untuk pengamat di lintang tinggi.

Dari pemaparan di atas, terlihat bahwa belum adanya satu kriteria visibilitas hilal yang benar-benar menjadi kesepakatan bersama.
Kesepakatan untuk menganut kriteria yang memiliki dasar-dasar ilmiah (astronomis) yang kokoh dan teruji secara empiris sangat diperlukan, sehingga diharapkan terwujudnya sistem penanggalan yang seragam bagi umat Islam.

\section{b. Garis Tanggal Qamariyah}

Kriteria visibilitas hilal berperan besar dalam menentukan mungkin tidaknya hilal diamati di suatu tempat. Namun karena perbedaan waktu dan tempat, ketinggian dan posisi hilal pun berbeda. Perbedaan tersebut terlihat dari perbedaan hasil ru'yatul hilal di berbagai tempat di dunia. Salah satu cara untuk memperlihatkan prediksi ketinggian hilal di berbagai tempat di dunia adalah dengan memuat garis tanggal qamariyah. Garis tanggal Qamariyah akan menunjukkan daerah yang kemungkinan dapat melihat hilal dan tidak dapat melihat hilal. Daerah yang berada di sebelah barat garis akan lebih awal melihat hilal daripada yang di sebelah timurnya. Oleh karena itu, sebagaimana yang disebutkan dalam Resolusi Penang tentang kalender Islam Internasional tahun 1988, secara umum suatu negara tidak boleh mengacu hasil pengamatan hilal negara-negara di sebelah baratnya. Misalnya, Indonesia tidak boleh mengacu kepada Arab Saudi.

Garis tanggal qamariyah sifatnya tidak tetap seperti garis tanggal Internasional (pada bujur $180^{\circ}$ ), tetapi berubah sesuai dengan perubahan kemungkinan penampakan hilal. Garis tanggal yang sederhana dibuat dengan menghitung pada daerah mana saja matahari dan bulan terbenam 
bersamaan. Ini merupakan syarat minimal ru'yatul hilal, yaitu bulan sudah wujud di ufuk barat. Di sebelah timur garis itu, hilal tidak mungkin teramati karena telah berada di bawah ufuk ketika matahari terbenam. Semakin ke arah barat kemungkinan ru'yatul hilal semakin besar.

Sebagai contoh, garis tanggal Dzulhijjah 1415 melintas lautan Atlantik. Wilayah di sebelah timur garis itu tidak mungkin mengamati hilal pada tanggal 29 April. Bulan berada di atas ufuk di wilayah Eropa, Afrika, Asia, dan Australia baru pada tanggal 30 April. Sehingga dengan kriteria wujudul hilal tersebut tanggal 1 Dzulhijjah jatuh pada tanggal 1 Mei, wukuf di Arafah tanggal 9 Mei, dan Idul Adha pada tanggal 10 Mei 1995. Garis tanggal seperti ini yang digunakan banyak ahli di Indonesia.

Bila memasukkan kriteria visibilitas hilal, yaitu beda waktu terbenam matahari dan bulan yang tergantung musim dan lintang tempat, garis tanggal itu lebih bergeser sekitar 20 jam ke arah barat. Garis tanggal Dzulhijjah 1415 yang dipublikasikan IICP menyatakan bahwa 1 Dzulhijjah untuk wilayah Eropa, Afrika Timur, Asia, dan Australia jatuh pada tanggal 2 Mei 1995. Maka wukuf di Arafah mestinya jatuh pada tanggal 10 Mei dan Idul Adha di wilayah itu baru dirayakan tanggal 11 Mei 1995. Hasilnya satu hari lebih lambat dari pada kriteria hisab yang biasa dilakukan di Indonesia.

\section{Konsep Kalender Islam Internasional Mohammad Ilyas \\ a. Biografi Intelektual Mohammad Ilyas}

Mohammad Ilyas adalah seorang fisikawan dan ahli mengenai atmosfer yang banyak menulis tentang Astronomi Islam. Ia lahir di India dan kini menetap di Malaysia. Dahulu ia seorang guru besar tamu Universiti Malaysia Perlis, sekarang ia menjabat sebagai Associate Professor Departemen Fisika Universiti Sains Malaysia, Penang dan mengepalai Unit Penyelidikan Ilmu Falak/Astronomy and Atmospheric ResearchUnit di universitas tersebut. Sebelumnya ia adalah guru besar Sains dan Atmosfira di Universiti Sains Malaysia. $^{1}$

Mohammad Ilyas juga merupakan salah seorang penggagas dan konsultan ahli berdirinya Pusat Falak Syeikh Tahir di Pulau Pinang. Ia telah banyak memberi sumbangan di bidang pengembangan ilmu falak, khususnya tentang Kalender Islam. Ia menggagas konsep "Garis Qamari Antarbangsa" atau biasa diistilahkan International Lunar Date Line (ILDL). Menurut Baharrudin Zainal dari segi kajian astronomi, khususnya berkaitan dengan teori visibilitas hilal, Ilyas adalah satusatunya ilmuwan muslim yang berada pada tahap sama dengan McNally (London), Le Roy Dogget

\footnotetext{
${ }^{1}$ Mohammad Ilyas, A Modern Guid to Astronomical Calculations of Islamic Calendar, Times \& Qibla (Kuala Lumpur: Berita Publishing Sdn. Bhd., 1984), 257.
} 
(Washington), Bradley E. Shaefer (NASA), dan Bruin. ${ }^{1}$

Bagi Ilyas, persoalan Kalender Islam tidak semata-mata persoalan sains, tapi perlu melibatkan kekuatan politik. Ilyas mengatakan “....dunia Islam memerlukan seorang Julian untuk menyatukan takwimnya.....". 2 Ilyas merupakan tokoh yang aktif dan produktif memperkenalkan ideidenya melalui berbagai buku dan jurnal. Hingga tahun 1998, Ilyas telah menghasilkan 11 judul buku dan 150 artikel yang dimuat di berbagai jurnal baik nasional maupun internasional. ${ }^{3}$

Karya-karya tersebut di antaranya A Modern Guide to Astronomical Calculations of Islamic Calendar, Times \& Qibla yang terbit pertama kali pada $1984 \mathrm{M} / 1405 \mathrm{H}$ oleh Berita Publishing Kuala Lumpur dan dicetak ulang oleh Washington DC pada 1992 M/1413 $\mathrm{H}$, New Moon's Visibility and International Islamic Calendar for The Asia-Pacific Region, 1407-1421 $H$ diterbitkan oleh Organization of Islamic Conference (OIC) Standing Committe on Scientific \& Technological Cooperation (COMSTECH) Islamabad, Pakistan dan Regional Islamic Da'wah Council of South East Asia \& Pacific (RISEAP) Kuala Lumpir, Malaysia dan pada tahun 1411-1415

1 Susiknan Azhari, Ensiklopedi Hisab Rukyat, Cet. II (Yogyakarta, Pustaka Pelajar, 2008), 147.

2 Mohammad Ilyas, Sistem Kalendar Islam dari Perspektif Astronomi (Kuala Lumpur: Dewan Bahasa dan Pustaka, 1997b), 162.

http://museumastronomi.com/penggagaskalender-islam-internasional/ diakses tanggal 18 Juli 2016.
Astronomy of Islamic Calendar diterbitkan oleh A.S. Noorden Kuala Lumpur, Calendar in Islamic Civilization Modern Issues, Islamic Astronomy and Science Development: Glorious Past, Challenging Future, dan Towards A Unified World Islamic Calendar. Karya terbarunya diterbitkan dalam bahasa Melayu dengan judul Kalender Islam dari Perspektif Astronomi. ${ }^{4}$ Melalui karya-karya tersebut akhirnya ia dikenal sebagai penggagas konsep Kalender Islam Internasional. ${ }^{5}$

\section{b. Konsep Kalender Islam Internasional}

Mohammad Ilyas tergerak untuk menyatukan dan mendamaikan umat Islam dengan menggagas penyatuan Kalender Islam Internasional. Munculnya gagasan ini tidak lepas dari situasi dan kondisi objektif umat Islam saat ini, misalnya di Malaysia terdapat kelompok tradisionalis, modernis dan reformis yang membahayakan ukhuwah Islamiyah dalam rangka mendesain kebangkitan Islam. Sebagai seorang muslim, Ilyas mengungkapkan merasa bertanggungjawab terhadap "problem keummatan", khususnya hal-hal yang berkaitan dengan Kalender Islam. Sehingga melalui keilmuwan falak yang digelutinya ia berupaya untuk menyatukan Kalender Islam.

\footnotetext{
${ }^{4}$ Susiknan Azhari, Hisab \& Rukyat Wacana untuk Membangun Kebersamaan di Tengah Perbedaan, Cet. I (Yogyakarta, Pustaka Pelajar, 2007), 25-26.

5 Susiknan Azhari, Ensiklopedi...., 147-148.
} 
Sebenarnya, dasar pemikiran atau ikhtiar metodologis (dalam bahasa Susiknan Azhari) Moh. Ilyas dalam mempersatukan Kalender Islam di dunia ini merupakan pengembangan dari ide-ide yang pernah dirintis oleh pemikir Islam sebelumnya, seperti Ibnu Taimiyah ${ }^{1}$, Ahmad Mohammad Syakir ${ }^{2}$, Abu Zahrah dan T.M. Hasbi AshShiddieqy ${ }^{3}$. Namun tokoh-tokoh ini hanya menyentuh pada tataran normatif-deduktif. Sedangkan gagasan Moh. Ilyas ini tidak hanya semata-mata normatif deduktif, namun didukung data empiris induktif dengan memanfaatkan sains modern. Untuk mendukung gagasannya, Moh. Ilyas melakukan riset \pm 20 tahun dari tahun 1973$1993 .{ }^{4}$

Gagasan penyatuan Kalender Islam Internasional Moh. Ilyas direalisasikan melalui proyek besar Kalenderisasi Islam Internasional. Proyek tersebut dilaksanakan melalui Internasional Islamic Calender Program (IICP) yang bermarkas di Universitas Sains Malaysia, Penang. Hasil-hasil riset ini kemudian disebarkan ke negaranegara Islam yang tergabung dalam Organisasi Konferensi Islam (OKI),

\footnotetext{
1 Ibnu Taimiyah, Al-Fatawa, juz XXV (Madinah: Dar al-Ihya' al-Lughah, t.th.), 105.

2 Ahmad Muhammad Syakir, Menentukan Hari Raya dan Awal Puasa, terj. K.H. Mahrous Ali, Cet. I (Surabaya, Pustaka Progressif, 1993), 29.

3 Hasbi Ash-Shiddieqy, Perbedaan Mathla Tidak Mengharuskan Kita Berlainan Hari Pada Memulai Puasa (Yogyakarta: Lajnah Ta'lif wan Nashr Fakultas Syari'ah IAIN Sunan Kalijaga Yogyakarta, 1971), 15. Rukyat....., 26.
}

kemudian didialogkan melalui pertemuan-pertemuan regional dan internasional. Misalnya Konferensi Turki tentang Unifikasi Kalender Islam Internasional pada tahun 1978 dan seminar penanggalan Islam Internasional pada tanggal 8-10 Juni 1988 di Malaysia, dan Konferensi Kalender Islam Internasional pada tanggal 8-10 Oktober 1991 di Penang Malaysia. $^{5}$ Namun sayangnya, usaha ini masih belum sepenuhnya mendapatkan respon yang baik dari masyarakat, bahkan Arab Saudi belum bisa menerima teori imkanur rukyat yang digagas Moh. Ilyas.

Melalui proyek IICP ini, Moh. Ilyas ingin membangkitkan ukhuwah Islamiyah di kalangan umat Islam yang semakin memudar karena sering terjadinya perbedaan dalam penetapan awal bulan Qamariyah. Kalender Islam Internasional yang digagas oleh Moh. Ilyas ini bukan dimaksudkan untuk berhari raya secara serempak seluruh umat Islam di dunia, karena jelas tidak mungkin. Yang diinginkan Moh. Ilyas adalah bagaimana menemukan teori-teori yang holistic sehingga dapat dirancang sistem tunggal dalam penyusunan Kalender Islam Internasional. Menurutnya, belum adanya kalender Islam Internasional sebagai bukti ketertinggalan umat Islam di bidang sains dan teknologi. Karena itu, perlu kerja keras dan mimpi besar untuk mewujudkannya melalui peningkatan pemahaman

5 Ibid, 27-28, Lihat juga Musa Mohamad (ed.), Towards Implementation of A unified Islamic Calendar, cet. I (PenangMalaysia: International Islamic Calendar Programme Mohamad, 1998). 
masyarakat tentang kalender Islam Internasional. ${ }^{1}$

Dalam rangka mewujudkan penyatuan kalender Islam Internasional, menurut Moh. Ilyas harus dilakukan melalui kajian ilmiah dengan data-data empiris yang diperoleh dari fenomena alam atas dasar kajian astronomi. Dalam hal ini, Moh. Ilyas memiliki dua gagasan, yakni: (1) Hisab Imkanur Rukyat, yang sekaligus untuk menemukan Garis Tanggal Qamariyah Internasional. Hisab ini dilakukan tidak hanya pada tempat tertentu, melainkan secara global. Hisab harus dilakukan di berbagai tempat untuk menemukan titik Imkanur Rukyat, (2) Garis Tanggal Qamariyah Internasional (International Lunar Date Line). Garis tersebut dihubungkan antar wilayah guna mendapatkan keseragaman hilal.

a) Hisab Imkanur Rukyat

Hisab imkanur rukyat dalam pemikiran Moh. Ilyas adalah awal bulan dinyatakan telah terjadi, bila setelah terbenam matahari (setelah terjadi ijtima') dan pada saat itu hilal dimungkinkan untuk dapat dilihat (dirukyat). Dalam hal ini, yang menjadi acuan adalah penentuan kriteria visibilitas hilal untuk dapat teramati. Dalam hisab ini, hanya ada satu kategori Imkanur rukyat, yaitu hilal mungkin terlihat dengan mata telanjang saja.

\footnotetext{
1 Susiknan Azhari, Penyatuan Kalender Islam, Satukan Semangat Membangun Kebersamaan Umat, dalam Kumpulan Papers Lokakarya Internasional Fakultas Syariah IAIN Walisongo Semarang, Penyatuan Kalender Hijriyah (Sebuah Upaya Pencarian Kriteria Hilal yang Obyektif Ilmiah), 2012, 84-85.
}

\begin{abstract}
Kelebihan hisab imkanur rukyat Ilyas atas hisab imkanur rukyat tradisional adalah bahwa hisab ini dilakukan tidak hanya lokal (pada tempat tertentu saja), melainkan dilakukan secara global. Artinya, hisab dilakukan di berbagai tempat di muka bumi untuk menemukan titik imkanur rukyat. Misalnya, hisab dimulai dari garis lintang $0^{\circ}$ guna menemukan pada titik mana di garis itu hilal mungkin terlihat pertama kali. Kemudian dilakukan hisab pada garis lintang berikutnya ke Utara dan ke Selatan dengan interval $5^{\circ}$ sampai $15^{\circ}$ guna menemukan titiktitik imkanur rukyat pada garis lintang itu.
\end{abstract}

Apabila semua itu telah selesai dilakukan dan telah ditemukan titiktitik imkanur rukyat pada berbagai garis lintang itu, maka titik-titik visibilitas hilal pertama yang dirukyat itu dihubungkan satu sama lainnya dengan sebuah garis, sehingga akan ditemukan suatu garis lengkung (parabolik atau semi parabolik) yang lengkungannya menjorok ke Timur. Garis itu akan memisahkan dua kawasan Bumi: kawasan sebelah Barat garis dan kawasan sebelah Timur garis.Kawasan sebelah Barat adalah kawasan yang mungkin bisa merukyat hilal dan kawasan sebelah Timur adalah kawasan yang tidak mungkin terjadi rukyat, dengan suatu catatan bahwa garis itu tidak bersifat eksak, melainkan garis yang kasar. Di sekitarnya terdapat daerah ketidakpastian rukyat antara $20^{\circ}$ hingga $30^{\circ}$. Garis itulah yang disebut dengan Garis Tanggal Qamariyah International atau International Lunar Date Line (ILDL). 
Perhitungan kalender didasarkan pula pada visibilitas hilal. Dalam pemberlakuan visibilitas hilal tersebut, Mohammad Ilyas membagi bumi menjadi tiga zona kalender yaitu zona barat (benua Amerika), zona tengah (Eropa, Asia Barat dan Afrika), dan timur (Asia Tengah dan Timur, Pasifik dan Australia). Pemberlakuan visibilitas hilal menurut ketetapan Moh. Ilyas sebagai berikut:

1) Jika visibilitas hilal telah memenuhi syarat di suatu lokasi di Zona Timur, maka Zona Tengah dan Barat mengikuti.

2) Jika visibilitas hilal telah memnuhi syarat di Zona Tengah, maka Zona Barat mengikuti dan Zona Timur akan menunggu satu hari berikutnya.

3) Jika visibilitas hilal telah memenuhi syarat di Zona Barat, maka Zona Timur dan Tengah akan menunggu 1 hari berikutnya.

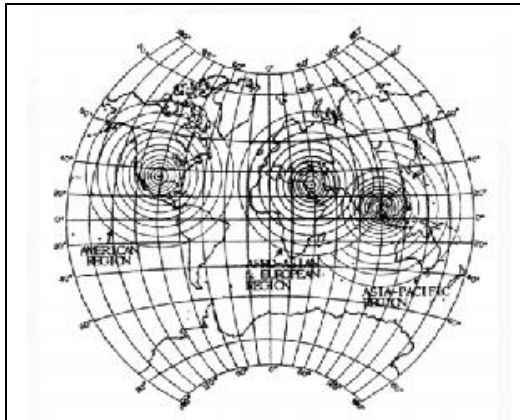

Gambar 1. Tiga zona kalender Ilyas

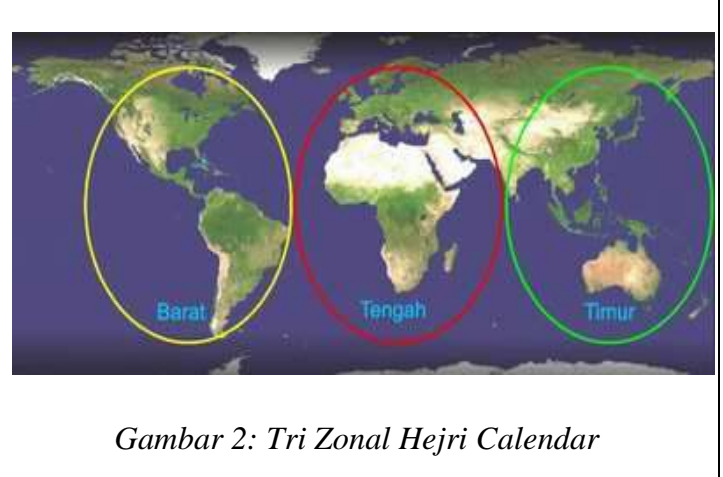

Gambar 2: Tri Zonal Hejri Calendar b) Garis Tanggal Qamariah Internasional

Garis Tanggal Qamariyah Internasional atau yang lebih dikenal dengan IIDL (International Lunar Date Line) adalah gagasan orisinal Moh. Ilyas pada tahun 1978. Gagasan ini diklaim sebagai proyek buat masa depan umat yang berusaha mengubah local oriented menjadi global oriented. Dengan menggunakan Garis Tanggal Qamariyah Internasional akan mudah ditentukan usia bulan (29 atau 30 hari) di suatu tempat di permukaan Bumi. Bagi Ilyas, garis tersebut digunakan karena paling mudah menghitungnya dan bisa dipakai sebagai pemandu awal oleh pengguna rukyat terpandu hisab sebelum menghitung data rukyat lokal. ${ }^{1}$

Konsep Garis Tanggal Qamariyah Internasionalini berdasarkan pada terlihatnya sedini mungkin pada tingkat global, tetapi menggunakan pendekatan usia yang sama pada waktu matahari terbenam dalam mewujudkan garis penampakan global. Ini juga

1 Mohammad Ilyas, New Moon's Visibility and International Islamic Calendar for The American Region 1407 H1421 H, (Malaysia: IICP, 1995), 14. Lihat juga Mohammad Ilyas dan M. Khalid-Taib, Pengantarbangsaan Kalendar Islam, Cet. I. (Malaysia: Universiti Sains Malaysia, 1989), 12-13. 
menghasilkan teknik konstruksi garis usia sama. Pada akhir tahun 1978 dibangun pula sistem perhitungan global yang makin canggih di tahuntahun berikutnya. Sistem ini memungkinkan konsep ILDL yang sudah mantap itu dipahami dengan lebih cepat.

Untuk ILDL, menggunakan Bujur geografis dihitung yang benarbenar memenuhi syarat penampakan minimum pada waktu matahari terbenam lokal karena secara prakteknya, bujur ini sama pentingnya dengan Garis Batas Tanggal Internasional. Data diplot pada proyeksi peta geografis (biasanya dua siklus), dan dengan menghubungkan titik-titik $\mathrm{P}$, bisa didapatkan garis penampakanhilal pertama (yakni ILDL) untuk setiap bulan. Pada proyeksi segi empat tepat, perbatasan mungkin terlihat berbentuk parabola dibandingkan dengan garis tegak lurus yang biasa kita gunakan untuk Garis Batas Tanggal Internasional. Namun, perlu diingat bahwa peta dua dimensi yang dilihat garis bujur sebagai garis tegak lurus hanyalah proyeksi untuk permukaan global hampir bola tiga dimensi yang garis bujurnya tidak paralel.

Garis Tanggal Qamariyah Internasional membagi bumi dalam dua bagian yang pada saat maghrib bulan masih di atas ufuk atau telah tenggelam. Seperti halnya Garis Tanggal Internasional (International Date Line yang berlaku sekarang) yang berfungsi menjadi garis batas tanggal Masehi, ILDL berfungsi menjadi batas tanggal Qamariyah, dalam arti kawasan sebelah Barat garis yang dapat melihat hilal memasuki bulan baru, sementara kawasan sebelah Timur yang belum dapat melakukan rukyat belum mulai bulan baru. Karena penampakan hilal yang tidak tetap setiap bulan, maka ILDL ini muncul secara berpindahpindah dari bulan ke bulan. Garis ini, apabila membelah dua suatu negara dapat ditarik ke arah Timur sesuai dengan batas Timur negara yang bersangkutan, sehingga tanggal Qamariyah pada negara itu dapat disatukan.Namun, pembagian ini menjadikan pemikiran Ilyas tetap mewariskan problem klasik, yaitu persoalan matla'. ${ }^{1}$

Garis Tanggal Qamariyah Internasional adalah pengembangan dari garis tinggi nol derajat, di mana ia menghubungkan titik-titik di permukaan Bumi yang bisa melihat Hilal (pada interval konfidensi $95 \%$ atau lebih) dengan bantuan teleskop/binokuler dalam kondisi cuaca cerah beberapa saat setelah terbenamnya Matahari. Konsep ILDL adalah sama dengan konsep Garis Batas Tanggal Internasional yang digunakan dalam penanggalan Gregorian (Masehi). Bedanya, jika letak Garis Batas Tanggal Internasional selalu tetap (yakni pada garis bujur $180^{\circ}$ ), maka letak ILDL selalu berubah-ubah bergantung pada konfigurasi Bulan-Matahari saat itu dan dari satu konjungsi ke konjungsi berikutnya. ${ }^{2}$

\footnotetext{
1 Susiknan Azhari, Hisab \& $\begin{aligned} \text { Rukyat...., } 31 . & \\ & \text { Mohammad Ilyas, The Quest for a }\end{aligned}$ Unified Islamic Calendar(Penang: International Islamic Calendar Programme, 2000), 15. Lihat jugaMohammad Ilyas, $A$ Modern Guid to Astronomical Calculations....., 115.
} 
c) Kriteria Visibilitas Hilal

Kriteria Visibilitas Hilal ini terkait erat dengan hasil hisab Imkanur Rukyat. Dalam menentukan kriteria visibilitas hilal, Ilyas menyempurnakan kriteria visibilitas hilal dengan menghubungkan antara dua parameter yaitu parameter ketinggian relatif geosentrikatau geocentric relative altitude (al-Irtifa' az-Zawi al-Markazi Bain asy-Syams wa al-Qamar Waqt al-Ghurub) dan parameter azimut relatif atau relative azimuth (Farq as-Samt Bain asySyams wa al-Qamar WaqtalGhurub). Menurut Ilyas, jarak sudut bulan-matahari haruslah mencapai angka 10,5 derajat pada beda azimut 0 derajat agar hilal dapat dilihat. Namun, menurut Odeh kriteria ini hanya memperhitungkan visibilitas hilal dengan pengamatan mata telanjang saja dan tidak bisa dipakai bila pengamatan dilakukan dengan teropong. ${ }^{1}$

\footnotetext{
1 http://www.icoproject.org/pdf/2001_UHD.pdf diakses tanggal 16 Juli 2016.
} 


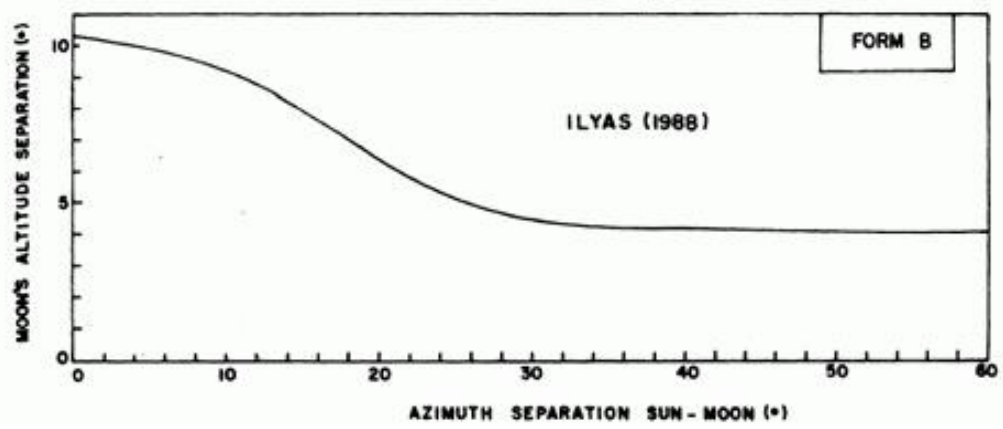

Gambar 3. Komposisi kriteria visibilitas hilal Ilyas

Lebih rincinya, visibilitas hilal yang membentuk kriteria Imkanur Rukyat Moh. Ilyas adalah sebagai berikut ${ }^{1}$ :

1) Beda tinggi Bulan-Matahari minimum agar hilal dapat teramati adalah 4 derajat, bila beda azimut Bulan-Matahari lebih dari 45 derajat.Bila beda azimutnya 0 derajat, perlu beda tinggi lebih dari 10,5 derajat.

2) Selain itu, sekurang-kurangnya Bulan 40 menit lebih lambat terbenam daripada Matahari dan memerlukan beda waktu lebih besar untuk daerah di lintang tinggi, terutama pada musim dingin.

3) Hilal juga harus berumur lebih dari 16 jam bagi pengamat di daerah tropis dan berumur lebih dari 20 jam bagi pengamat di lintang tingg

1 Mohammad Ilyas, Astronomi of Islamic Calendar, Cet. I (Kuala Lumpur: Pustaka Hayathi, 1997a), 97-98. Lihat juga Mohammad Ilyas, Sistem Kalendar Islam dari Perspektif Astronomi, 101-103. 
Tabel 1. Kriteria Visibilitas Hilal

Tinggi Hilal Fungsi dari Perbedaan Azimuth Matahari dan Bulan (Ilyas,

1997a: 153)

\begin{tabular}{|c|c|}
\hline Beda Azimuth Bulan dan Matahari & Tinggi Hilal $( \pm \mathbf{0 , 5}$ derajat $)$ \\
\hline 0 derajat & 10,5 derajat \\
\hline 10 derajat & 9,2 derajat \\
\hline 20 derajat & 6,4 derajat \\
\hline 30 derajat & 4,5 derajat \\
\hline 40 derajat & 4,2 derajat \\
\hline 60 derajat & 4,0 derajat \\
\hline Kriteria visibilitas kemudian, tepatnya pada abad ke-6
\end{tabular}

berdasarkan tinggi bulan dan beda azimut bulan dan matahari ini kuat dipengaruhi oleh jarak bulan-bumi dan posisi lintang ekliptika bulan, bukan hanya faktor geografis. Kriteria ini merupakan kriteria ketiga dari tiga kriteria yang dibuat oleh Moh. Ilyas.

Kriteria visibilitas hilal yang dikonsep oleh Moh. Ilyas ini diramu dari berbagai kriteria visibilitas hilal para penemu sebelumnya. Dengan mengurangi kekurangan yang ada serta menambahkan kemungkinan kelebihan yang dapat diambil, Moh. Ilyas merumuskan konsepnya sendiri. Konsep kriteria visibilitas hilal merupakan perjalanan yang sangat panjang. Konsep kriteria ini telah dimulai sejak era Babilonia yang memiliki kriteria Babilon dan dikenal memiliki bentuk paling sederhana, berupa $a_{S}{ }^{1} \geq 12^{\circ}$. Untuk wilayah lembah Mesopotamia (lintang $\left.23^{\circ} \mathrm{LU}\right), a_{s} \geq 12^{\circ}$ bisa ditranslasikan sebagai selisih terbenamnya Matahari dan Bulan (Lag) $\geq 48$ menit. Secara terpisah hal yang sama ternyata juga ditemukan astronom India kuno berabad-abad

\footnotetext{
Bulan-Matahari.
}

M. $^{2}$

Pada masa awal peradaban Islam, dilatarbelakangi kebutuhan pemenuhan kalender Hijriyyah, ilmu falak berkembang dengan cendekiawan Muslim mulai membakukan tradisi merukyat hilal sekaligus mengembangkan inovasi dalam menyusun kriteria visibilitas empirik. Inovasi tersebut secara garis besar menghasilkan dua kelompok besar kriteria visibilitas. Kelompok pertama menekankan visibilitas sebagai fungsi $a_{L}^{3}$. Al-Khwarizmi (780-850 M) memeloporinya dengan mendeduksi hilal sebagai Bulan yang mempunyai $a_{L}>9,5^{\circ}$. Ibn Maimun (731-861 M) mengikutinya sembari memperhitungkan faktor musim semi dan musim gugur serta memperkenalkan besaran $\mathrm{a}_{\mathrm{D}}{ }^{4}$ sehingga hilal merupakan Bulan dengan $9^{\circ} \leq a_{L} \leq 24^{\circ}$ dan $a_{D}+a_{L} \geq 22^{\circ}$. Termasuk pula di dalamnya ibn Qurra (826-901), yang membentuk

\footnotetext{
2 Muh. Ma'rufin Sudibyo, Data Observasi Hilaal 2007-2009 di Indonesia(Yogyakarta: Lembaga Pengkajian dan Pengembangan Ilmu Falak Rukyatul Hilal IndonesiaSudibyo, 2012), 2-3.

${ }^{3} \mathrm{a}_{\mathrm{L}}$ adalah elongasi atau jarak sudut Bulan-Matahari.

${ }^{4} \mathrm{a}_{\mathrm{L}}$ adalah selisih altitude BulanMatahari.
} 
ulang kriteria ibn Maimun sehingga menjadi $11^{\circ} \leq a_{L} \leq 25^{\circ}$.

Sementara kelompok kedua tetap berpegang pada kriteria Babilon. As-Sufi (903-986 M), ibn Sina (980-1037 M), ath-Thusi $(1258-1274$ M) dan al-Kashani (abad ke-15 M) menggunakan bentuk dasar kriteria Babilon $\left(a_{s} \geq\right.$ $12^{\circ}$ ) sementara al-Battani (850-929 M) dan al-Farghani (abad ke-9 M) berinovasi dengan merumuskan $a_{S}<$ $12^{\circ}$ namun hanya untuk $a_{L}$ besar. Meski begitu terdapat perkecualian. Al-Biruni (973-1048 M) misalnya, juga mengembangkan konsep visibilitas $^{2}$ sebagai fungsi antara $a_{D}$ dan $\mathrm{DAz}^{3}$.

Semua kemajuan ini dipungkasi dipungkasi masa stagnasi 3,5 abad lebih yang bermula sejak awal abad ke-15 M. Stagnasi ini berakhir dengan mulai munculnya kriteria visibilitas modern, yang berawal pada pertengahan abad ke19 M. Observasi Schmidt selama periode 1859-1877 di Athena (Yunani) menghasilkan 72 data. Analisis Fotheringham terhadap data Schmidt menghasilkan benih kriteria visibilitas empirik modern, yang bentuknya mengikuti gagasan alBiruni. Maunder (1911) memperbaiki model Fotheringham

1 Muh. Ma'rufin Sudibyo, Data Observasi Hilaal 2007-2009 di Indonesia, 23.Lihat juga Mohammad Ilyas,Astronomi of Islamic Calendar, 11.

2 Konsep visibilitas menurut alBiruni inilah yang kelak melahirkan konsep visibilitas modern. Matahari.

${ }^{3}$ DAz adalah selisih azimuth Bulan-

4 Muh. Ma'rufin Sudibyo, Data Observasi Hilaal 2007-2009 di Indonesia, 3. Lihat juga Mohammad Ilyas, Astronomi of Islamic Calendar, 11. dengan menambahkan sejumlah data sehingga terbentuk kriteria Fotheringham-Maunder : $\mathrm{a}_{\mathrm{D}} \geq-$ $0,01 \mathrm{DAz}^{2}-0,05 \mathrm{DAz}+11$. Meski demikian hingga dekade 1970-an kriteria ini tidak benar-benar diterapkan untuk penyusunan kalender. Dengan hubungan $\cos a_{L}=$ $\cos \mathrm{DAz} \cos \mathrm{a}_{\mathrm{D}}$, diperoleh nilai $\mathrm{a}_{\mathrm{L}}$ minimum $11^{\circ}$ atau sama dengan usulan ibn Qurra satu millenium sebelumnya. Nilai ini juga konsisten dengan batas Danjon $7^{\circ}$ yang secara empirik diperoleh A. Danjon dari 72 data terkait panjang sabit Bulan sebagai hasil observasi pada periode 1932-1936 M.

Kriterika visibilitas modern hilal memasuki ranah baru saat Bruin $^{5}$ memperkenalkan kriteria visibilitas fisis modern dengan variabel ${ }^{6} \mathrm{~W}$ dan $\mathrm{a}_{\mathrm{D}}: \mathrm{a}_{\mathrm{D}} \geq-0,5623 \mathrm{~W}^{3}$ $+3,9512 \mathrm{~W}^{2}-9,4878 \mathrm{~W}+12,4203$. Dengan hubungan $\mathrm{W}=\mathrm{R}(1-\cos \mathrm{DAz}$ $\left.\cos a_{D}\right)$ dimana nilai $R$ dianggap konstan 15', maka persamaan tersebut dibentuk ulang menjadi : $\mathrm{a}_{\mathrm{D}} \geq-0,03 \mathrm{DAz}^{2}+0,14 \mathrm{DAz}+10,136$ (akurat untuk DAz $<20^{\circ}$ ). Kriteria Bruin ini, meskipun tidak sempurna, lantas menjadi dasar kriteria-kriteria berikutnya.

Ilyas merevisi kriteria Bruin sehingga $a_{L} \quad$ minimumnya bersesuaian dengan $a_{L}$ minimum menurut Fotheringham-Maunder. Ini membuat kriteria FotheringhamMaunder bisa diterapkan di kawasan

5 F. Bruin adalah salah satu cendekiawan Muslim kontemporer yang mengkaji sifat-sifat fisis visibilitas Bulan dalam hubungannya dengan hilal dan kalender Hijriyyah. Ia tinggal di Beirut (Lebanon) dan menelurkan kriteria Bruin pada 1977 TU.

${ }^{6} \mathrm{~W}$ adalah lebar sabit Bulan. 
lintang tinggi (subtropis dan lingkar kutub) sehingga melahirkan kriteria baru yang disebut kriteria komposit Ilyas. Selama periode 1981-1988 M ia menelurkan tiga kriteria visibilitas, masing-masing kriteria Ilyas A, Ilyas B dan Ilyas C.

Pada tahun 1981-1984, Ilyas menggunakan kriteria Ilyas A, yaitu $\mathrm{a}_{\mathrm{D}}(\Delta \mathrm{Z}) \geq \mathrm{f}\left(\mathrm{a}_{\mathrm{L}}, \quad \mathrm{Z}\right)$ di mana menggabungkan dua kriteria yang bebas. Ilyas memplot kurva berdasarkan data observasi dengan ketinggian bulan saat matahari terbenam terhadap busur cahaya $\left(a_{\mathrm{L}}\right)$ atau elongasi matahari-bulan atau pemisahan sudut antara matahari dan bulan. Dari kurva ini, digambarkan bahwa hilal akan terlihat jika terletak di atas kurva dan tidak terlihat jika hilal berada di bawah kurva.

Selanjutnya pada tahun 1984, Ilyas mengemukakan kriteria Ilyas B, yaituUsia $\geq \mathrm{f}$ (lintang, musim, tahun), sebuah kriteria dengan pendekatan yang lebih sederhana. Kriteria ini kembali ke kriteria zaman Babilonia, Kriteria ini digunakan terutama pada lintang rendah. Adapun untuk lintang lain, Ilyas memodifikasi dari Babilonia dengan kompensasi dalam lintang. Kelambatan bulan terbenam pada matahari terbenam lokal dihitung untuk setiap bujur, berbagai lintang dan 70 lunasi berturut-turut. Hasilnya adalah pada lintang $0^{\circ}$, selisih terbenam mataharibulanminimum $41( \pm 2)$ menit, pada lintang $30^{\circ}$, selisihnya $46( \pm 4)$ menit, pada lintang $40^{\circ}$, selisihnya 49 ( \pm 9$)$ menit, dan pada lintang $50^{\circ}$, selisihnya 55( \pm 15$)$ menit.

Dalam kriteria Ilyas B ini, prediksi awal bulan visibilitas sangat konstan dari lintang rendah sampai pertengahan.Namun, kriteria ini adalah kriteria perkiraan sederhana. Pada lintang tinggi (misalnya $60^{\circ}$ ), data ini tidak konsisten. Hal ini karena sudut elongasi yang besar. Data sedikit berpencar pada musim semi, musim gugur dan musim dingin, dan musim panas datanya tersebar. Hal ini menunjukkan bahwa prediksi menunjukkan bahwa kriteria ini memiliki ketidakpastian yang besar. Dalam kriteria ini terlihat bahwa keberadaan musim pada lintang yang lebih tinggi tidak dipertimbangkan. ${ }^{1}$

\footnotetext{
${ }^{1}$ Xin, Leong Wen, Lunar Visibility and the Islamic Calendar(Singapore: Departement of Mathematics National University of Singapore, 2001), 21.
} 


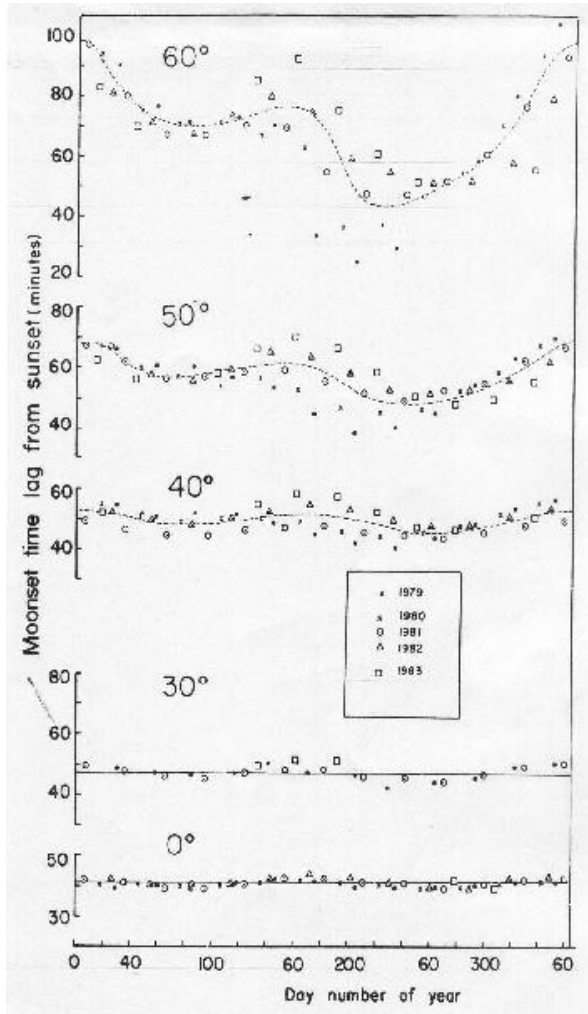

Gambar 4. Data kriteria Ilyas B

Dan yang terakhir kriteria Ilyas C 1988 yaitu (Tinggi Bulan, Azimuth relatif antara bulan dan matahari). Pada tahun 1988, Ilyas membuat sedikit modifikasi dari kriteria Ilyas A menggunakan rumus trigonometri. Sebuah kurva yang diplot dengan ketinggian bulan melawan azimuth relatif mataharibulan. Sudut elongasi $a_{L}$ atau azimuth relatif $\mathrm{A}_{\mathrm{Z}}$ diperpanjang, alurnya tidak dapat terus lurus karena akan melebihi garis, alurnya juga tidak dapat diteruskan ke bawah karena pada lintang tinggi, $\mathrm{Z}$ kemudian akan menjadi negatif, yaitu bulan tidak dapat dilihat. Kriteria inilah yang disebutkan pada awal subbab ini, yakni kriteria Ilyas yang menghubungkan antara dua parameter yaitu parameter ketinggian relatif geosentrikdan parameter azimut relatif. ${ }^{1}$

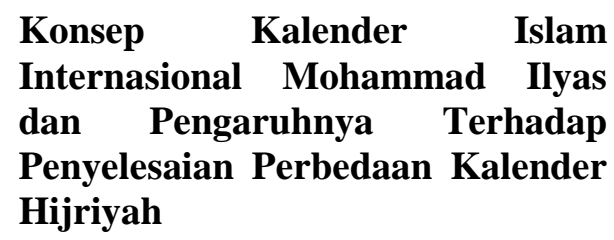

Islam Internasional yang dikemukakan Ilyas memiliki dua kriteria utama, yakni Hisab Imkanur Rukyat dan Garis Tanggal Qamariyah Internasional. Di samping itu, Mohammad Ilyas mengemukakan kriteria Visibilitas Hilal yang menggabungkan antara ketinggian bulan dan azimut relatif sebagaimana yang telah disebutkan

\footnotetext{
${ }^{1}$ Ibid.
} 
dalam pembahasan. Gagasan Moh. Ilyas ini memberikan wacana baru dalam konteks keilmuwan falak khususnya dalam penyatuan kalender Islam.

Dalam konteks Garis Tanggal Qamariyah Internasional terkait erat dengan wilayah yang negara yang akan dilewati garis 0 derajat, di mana merupakan batas antara bulan bagian wilayah yang mungkin melihat hilal dan tidak dapat. Dengan garis tanggal ini dapat memudahkan untuk mengetahui bagian wilayah yang mungkin dapat melihat dan tidak. Namun, garis tanggal ini pun menyisakan masalah yaitu mathla' (karena garis tanggal selalu berubahubah tergantung konfigurasi Bulan dan Matahari).

Suatu saat garis tanggal ini tidak membelah wilayah Negara, namun pada saat yang lain akan melintas dan membelah wilayah negara. Kemungkinan ini membawa pada konsekuensi terjadinya perbedaan tanggal dalam kalender hijriyah di wilayah negara tersebut. Namun, untuk di Indonesia hal ini dapat dijembatani dengan adanya konsep wilayatil hukmi (berlakunya hasil hisab-rukyat dalam satu kesatuan wilayah hukum, yakni seluruh wilayah negara).

Menurut T. Djamaludin, konsep Garis Batas Tanggal Qamariyah sangat prospektif, akan tetapi masih menyisakan persoalan karena umat Islam masih memiliki double standart dan hidup dalam dua sistem penanggalan (kalender Masehi dan Qamariyah). Definisi hari berdasarkan Garis Tanggal Internasional yang telah disepakati adalah melintasi garis bujur 180 derajat di Samudera Pasifik, sedangkan definisi hari (awal bulan Qamariyah) berdasarkan garis tanggal Qamariyah yang tidak tetap (tergantung posisi Bulan dan Matahari).

Walaupun demikian, menurut penulis standart antara Kalender Masehi dan Qamariyah memang harus dibedakan, karena keduanya memiliki sistem yang berbeda. Walaupun umat Islam memiliki double standart yakni Kalender Masehi dan Hijriyah, umat Islam harus membiasakan untuk dapat menerima perbedaan antara keduanya. Di mana Kalender Masehi memiliki Garis Batas Tanggal Internasional yang tetap karena sistemnya menggunakan terbit Matahari dengan jumlah hari dalam satu bulan sudah ditetapkan, sedangkan Kalender Qamariyah memiliki Garis Tanggal Qamariyah Internasional yang berbeda-beda setiap bulannya, mengikuti visibilitas hilal. Hal ini karena konsep Kalender Qamariyah tergantung pada penampakan bulan yang tidak tetap setiap bulannya. Dengan demikian, kita tidak bisa selalu membandingbandingkan konsep Garis Batas Tanggal yang ada pada Kalender Masehi dengan Kalender Qamariyah karena konsep dan sistem keduanya memang berbeda.

Di sisi lain, Garis Tanggal Qamariyah Internasional masih menyisakan masalah yakni masih lebarnya zona ketidakpastian di sepanjang garis ILDL. Adanya zona ketidakpastian, sebagai konsekuensi logis dari observasi, dapat menghasilkan perbedaan penafsiran dalam mendefinisikan hilal dan implementasinya. Kriteria Ilyas ini menghasilkan zona ketidakpastian 
sebesar antara $20^{\circ}$ hingga $30^{\circ}$. Bila dibandingkan dengan kriteria Yallop dan Audah yang memiliki lebar zona ketidakpastian sebesar $\pm 54^{\circ}$, zona ketidakpastian kriteria Ilyas termasuk kecil. Namun demikian, dengan adanya zona ketidakpastian tersebut, garis ILDL sebenarnya bukanlah sebuah garis yang tipis seperti halnya Garis Batas Tanggal Internasional dalam kalender Gregorian, melainkan garis sangat tebal dengan ketebalan $20^{\circ}-30^{\circ}$. Di dalam garis ini, visibilitas Bulan sebagai hilal merupakan fungsi peluang (probabilitas) yang nilainya antara 50 $\%$ hingga $75 \%$.

Dengan besarnya zona ketidakpastian di atas, kesalahan dalam kriteria Ilyas diperkirakan sekitar kurang lebih 1 derajat atau kesalahan bujur yang sama, yaitu kuranglebih 30 derajat. Penelitian selanjutnya untuk perkembangan teori kriteria visibilitas hilal, harus diarahkan untuk mengurangi kesalahan ini dari segi observasi atau teori -dengan menggunakan parameter fisik- atau keduanya. Kriteria usia bulan dan kriteria susulan bulan terbenam yang baru diterbitkan oleh Ilyas memberikan dasar yang lebih mudah untuk membuat anggaran perkiraan. Kriteria susulan bulan terbenam agak tepat untuk kebanyakan lintang praktis (pada lintang yang sangat tinggi, faktor cuaca menjadi pertimbangan yang serius). ${ }^{1}$

Adapun dalam hal kriteria visibilitas hilal M. Ilyas yaitu yang mempertimbangkan ketinggian hilal dan azimut relatif, nampaknya tidak

1 Mohammad Ilyas, Sistem Kalendar Islam dari Perspektif Astronomi, 111. dapat digunakan untuk di Indonesia. Rekor pengamatan hilal termuda bisa dijadikan bukti kelemahan kriteria beda posisi dan umur hilal ini. Rekor keberhasilan pengamatan hilal termuda tercatat pada umur hilal 13 jam 24 menit yang teramati pada tanggal 5 Mei 1989 (6 Mei 01:10 UT) di Houston, Amerika Serikat, mengalahkan rekor sebelumnya 14 jam 30 menit pada tanggal 2 Mei 1916 di Inggris. Hasil ini jauh di bawah kriteria umur bulan. $^{2}$

Menurut kriteria umur bulan, pada bulan Mei umur minimal kenampakan hilal dari daerah lintang tinggi: 26 jam (daerah lintang lebih dari 50 derajat) dan 16 jam (daerah lintang 30 derajat). Beda azimut dan ketinggiannya di bawah batas kriteria posisi. Dua pengamatan awal Mei itu memang saat terbaik untuk mengamati hilal termuda karena bulan berada pada jarak terdekat dengan bumi (perigee), ditambah lagi dengan lintang ekliptika bulan mendekati maksimum (sekitar $5^{\circ}$ ). Pada tanggal 2 Mei 1916 bulan berada pada posisi lintang ekliptika $+4^{\circ} 48^{\prime}$ dan pada tanggal 5 Mei 1989 pada posisi $+4^{\circ} 58^{\prime}$. Beda waktu terbenam matahari-bulan kedua kasus tersebut memenuhi kriteria beda waktu terbenam: pada tanggal 2 Mei 1916 beda waktu terbenam adalah 57 menit (sesuai kriteria untuk lintang lebih dari $50^{\circ}$ ) dan pada tanggal 5 Mei 1989 beda waktunya 41 menit (sesuai dengan kriteria untuk lintang $30^{\circ}$ ).

Dari ketiga kriteria Ilyas, yang terbaik adalah kriteria beda waktu terbenam. Faktor posisi bulan-

\begin{tabular}{ll}
\hline 2 & http://media.isnet. \\
org/isnet/Djamal/almanak.html diakses \\
tanggal 16 Juli 2016.
\end{tabular}


matahari dan keadaan atmosfer sudah tercakup di dalamnya. Variasi musiman pada kriteria tersebut kecil untuk daerah tropik dan makin membesar sejalan dengan pertambahan lintang tempat. Kriteria beda waktu terbenam sangat dominan dipengaruhi oleh keadaan atmosfer setempat. Variasi musiman untuk daerah lintang tinggi sangat dipengaruhi oleh temperatur, pada musim dingin cenderung kenampakan hilal mensyaratkan beda waktu terbenam yang lebih besar.

Namun dalam prakteknya, kriteria visibilitas hilal ini belum banyak di pakai, mungkin karena belum memasyarakat. Kriteria utama yang banyak di pakai adalah bulan sudah di atas ufuk yang pada hakikatnya syarat wujudul hilal sebagaimana yang digunakan di Indonesia. Untuk kriteria visibilitas hilal ini masih perlu kajian dan observasi yang konsisten dan berkualitas agar dapat menghasilkan data yang akurasinya dapat dibuktikan secara empiris. Dengan kriteria visibilitas hilal yang mapan, maka dapat membatasi laporan rukyat yang diterima atau ditolak. Sehingga konsep Kalender Islam Internasional dapat diwujudkan.

Tidak dapat dipungkiri bahwa Mohammad Ilyas merupakan salah seorang pioner dalam penelitian mengenai visibilas hilal yang juga pertama kali mengusulkan konsepInternational Lunar Date Line. Konsep ini telah banyak membuka mata dan mengispirasi pemikir lain seperti Mohammad Syaukat 'Audah, Jamaluddin Abd Ar-Raziq, dan Nidhal Guessoum. Konsep ILDL itu sendiri mendapat sambutan dari berbagai pihak, salah satunya adalah Dr. Monzur Ahmed dari Inggris yang kemudian mengembangkannya dalam bentuk software yang sangat terkenal dalam masalah hilal yaituMooncalc.

Namun demikian, konsep ini tentu tidak secara langsung dan instan diterima semua pihak. Banyak yang menolak dengan alasan masih menyisakan banyak pertanyaan dan memerlukan kajian lebih mendalam, sehingga para peneliti dan ilmuwan Muslim lain mengembangkan dan memperbaiki kesalahan-kesalahan yang ada dalam konsep ILDL Moh. Ilyas. Ini merupakan salah satu pengaruh yang dihasilkan dari gagasan Moh. Ilyas. Para peneliti dan ilmuwan muslim kemudian membuat banyak konsep baik dalam hal visibilitas hilal maupun zona waktu, sehingga banyak konsep kalender Islam yang berkembang.

Pengaruh terbesar yang dihasilkan dari Moh. Ilyas dalam penyatuan kalender Islam Internasional adalah munculnya model kalender zonal dan kalender terpadu. Kalender zonal dipelopori oleh Mohammad Syaukat 'Audah di mana wilayah dunia dibagi dalam beberapa bagian. Dalam hal ini, Mohammad Syaukat 'Audah membagi menjadi dua zona / bizonal, zona barat dan zona timur berdasarkan kriteria imkanurrukyat. Zona Timur meliputi kawasan dari garis $180^{\circ} \mathrm{BT}$ ke arah barat hingga $20^{\circ} \mathrm{BB}$ yang mencakup empat benua (Australia, Asia, Afrika, dan Eropa). Sedangkan Zona Barat meliputi kawasan dari posisi $20^{\circ} \mathrm{BB}$ hingga mencakup kawasan barat Amerika Utara dan Amerika Selatan. Adapun kalender terpadu dipelopori oleh Jamaluddin Abd Ar-Raziq dan 
Khalid Shaukat, wilayah dunia dalam satu waktu sehingga hanya ada satu zona yaitu zona dunia. ${ }^{1}$

Pada dasarnya pembagian zona baik satu, dua atau tiga zona ataupun pembagian mathla' seperti wilayatil hukmi tidak memiliki dasar dasar syari'at dan ilmiah. Pembagian zona itu hanya disesuaikan dengan wilayah sebaran penduduk dan geopolitik ataupun geografis tempat. Adapun dalam hal astronomisnya tidak dipertimbangkan. Sehingga, konsep-konsep pembagian zona dan mathla' tersebut tidak dapat dijadikan acuan tetap dan final.

Dengan demikian, dari berbagai konsep kalender Islam dengan pembagian zonanya tersebut, belum ada satu konsep yang dapat diterima oleh seluruh umat Islam sebagai konsep kalender Islam Internasional, termasuk juga konsep kalender Islam Universal Moh. Ilyas. Perbedaan Kalender Hijriyah juga terus berlanjut. Dengan demikian, sebenarnya konsep kalender yang ditawarkan Mohammad Ilyas belum bisa menyelesaikan masalah perbedaan Kalender Hijriyah. Namun konsepnya telah mampu mempengaruhi dunia dengan membuka mata Internasional tentang pentingnya Kalender Hijriyah Internasional segera diwujudkan dan membuka jalan untuk penyatuan Kalender Islam.

Untuk mewujudkan kalender Islam Internasional, tentu perlu kajian lanjut dan intensif terkait dengan sistem kalender internasional baik dari segi kriteria visibilitas hilal dan garis tanggal qamariyah

1 Syamsul Anwar, Hari Raya \& Problematika Hisab-Rukyat(Yogyakarta: Suara Muhammadiyah, 2008), 115-147. internasional. Dengan penelitian dan melakukan dialog universal yang berkesinambungan, maka kesepatan akan terwujud.Sebuah konsep dan kriteria visibilitas hilal akan digunakan oleh umat Islam di seluruh dunia. Dan hal ini harus diusahakan sesegera mungkin sebelum masalah ini menjadi sangat akut. Dengan demikian, Kalender Islam Internasional yang didambakan seluruh umat Islam di dunia dapat terwujud.

\section{Kesimpulan}

Gagasan penyatuan Kalender
Islam Internasional yang dikemukakan Ilyas memiliki dua kriteria utama, yakni Hisab Imkanur Rukyat dan Garis Tanggal Qamariyah Internasional memberikan wacana baru dalam konteks keilmuwan falak. Namun, garis tanggal ini menyisakan masalah yaitu mathla' (karena garis tanggal selalu berubah-ubah tergantung konfigurasi Bulan dan Matahari). Namun, untuk di Indonesia hal ini dapat dijembantani dengan adanya konsep wilayatil hukmi (berlakunya hasil hisab-rukyat dalam satu kesatuan wilayah hukum, yakni seluruh wilayah negara).

Konsep Garis Tanggal Qamariyah Internasional masih agak sulit diterapkan karena umat Islam menggunakan double standart yakni Kalender Masehi dan Hijriyah. Namun keduanya tidak dapat dibanding-bandingkan karena konsep dan sistem keduanya memang berbeda. Di samping itu, Garis Tanggal Qamariyah Internasional masih menyisakan masalah lebarnya zona ketidakpastian di sepanjang garis ILDL, yakni sebesar antara $20^{\circ}$ 
hingga $30^{\circ}$. Dengan besarnya zona ketidakpastian di atas, kesalahan dalam kriteria Ilyas diperkirakan sekitar kurang lebih 1 derajat atau kesalahan bujur yang sama, yaitu kuranglebih 30 derajat. Perlu penelitian lanjut untuk perkembangan teori kriteria visibilitas hilal dan harus diarahkan untuk mengurangi kesalahan ini.

Sedangkan dalam hal pengaruh pemikiran Moh. Ilyas terhadap perbedaan Kalender Hijriyah, konsep kalender yang ditawarkan Mohammad Ilyas memang belum bisa menyelesaikan masalah perbedaan Kalender Hijriyah. Namun dalam diskursus Kalender Islam Internasional, nama Mohammad Ilyas tidak pernah lupa untuk disebut karena memang ia adalah penggagas awal Kalender Islam. Terlepas dari beberapa masukan terkait dengan kriteria yang digagasnya, pemikiran Ilyas telah banyak membuka mata dan pikiran para intelektual muslim khususnya yang bergulat dalam keilmuan hisab rukyat untuk mengupayakan penyatuan kalender hijriyah.[]

\section{Daftar Pustaka}

Ash-Shiddieqy, Hasbi, 1971, Perbedaan Mathla Tidak

Mengharuskan Kita

Berlainan Hari Pada

Memulai Puasa,

Yogyakarta: Lajnah Ta'lif

wan Nashr Fakultas

Syari'ah IAIN Sunan

Kalijaga Yogyakarta

Azhari, Susiknan, 2007, Hisab \& Rukyat Wacana untuk Membangun Kebersamaan di Tengah Perbedaan,

Yogyakarta, Pustaka Pelajar, Cet. I

, 2008, Ensiklopedi Hisab Rukyat, Yogyakarta, Pustaka Pelajar, Cet. II , 2012, Penyatuan Kalender Islam, Satukan Semangat Membangun Kebersamaan Umat, Kumpulan Papers Lokakarya Internasional Fakultas Syariah IAIN Walisongo Semarang, Penyatuan Kalender Hijriyah (Sebuah Upaya Pencarian Kriteria Hilal yang Obyektif Ilmiah)

Anwar, Syamsul, 2008, Hari Raya \& Problematika HisabRukyat, Yogyakarta, Suara Muhammadiyah

, Makalah "Kalender Hijriah Global, Penyatuan Jatuhnya Hari Arafah"

Departemen Pendidikan dan Kebudayaan, 2008, Kamus Besar Bahasa Indonesia, Jakarta: Balai Pustaka

http://museumastronomi.com/pengga gas-kalender-islaminternasional/

http://media.isnet.org/isnet/Djamal/al manak.html

http://media.isnet.org/iptek/Etc/Hilal Tampak.html

http://www.icoproject.org/pdf/2001_ UHD.pdf

Ilyas, Mohammad, 1984, A Modern Guid to Astronomical Calculations of Islamic Calendar, Times \& Qibla, Kuala Lumpur, Berita Publishing Sdn. Bhd.

dan M. KhalidTaib,1989,Pengantarbang saan Kalendar Islam, 
MalaysiaUniversiti Sains

Malaysia, Cet. I. 1995, New Moon's Visibility and International Islamic Calendar for The American Region $1407 \mathrm{H}$ - 1421 H, Malaysia, IICP ,1997a,Astronomi of Islamic Calendar, Kuala Lumpur, Pustaka Hayathi, Cet. I 1997b, Sistem Kalendar Islam dari Perspektif Astronomi, Kuala Lumpur, Dewan Bahasa dan Pustaka

, 2000, The Quest for a Unified Islamic Calendar, Penang, International Islamic Calendar Programme

Mohamad, Musa (ed.).1988,Towards Implementation of $A$ unified Islamic Calendar, cet. I, Penang-Malaysia, International Islamic Calendar Programme

Sudibyo, Muh. Ma'rufin, 2012, Data Observasi Hilaal 20072009 di Indonesia, Yogyakarta, Lembaga Pengkajian dan Pengembangan Ilmu Falak Rukyatul Hilal Indonesia

Syakir,

Ahmad

Muhammad,1993,Menentu kan Hari Raya dan Awal Puasa, terj. K.H. Mahrous Ali, Cet. I, Surabaya, Pustaka Progressif

Taimiyah, Ibnu, t.th., Al-Fatawa, Madinah, Dar al-Ihya' alLughah, juz XXV

Saksono, $\quad$ Tono, 2007, Mengkompromikan Rukyat \& Hisab, Jakarta: P.T. AmythasPublicita
Xin, Leong Wen, 2001, Lunar Visibility and the Islamic Calendar, Singapore, Departement of Mathematics National University of Singapore 
